\begin{tabular}{ll}
\hline CURRENT & ISSN: 0973-4929, Vol. 13, №. (2) 2018, Pg. 259-269 \\
WORLD & Current World Environment
\end{tabular}

ENYRONMENT Journal Website: www.cwejournal.org

\title{
Impact of Biomedical Waste on Cuttack City
}

\author{
PUSPALATA PAL ${ }^{1 *}$ and DHIRENDRA KUMAR SARANGI ${ }^{2}$ \\ ${ }^{1}$ Ravenshaw Government Jr. College, Cuttack, India. \\ ${ }^{2}$ Former Principal \& Head, Deptt. of Zoology J.K.B.K. Government College, Cuttack, India.
}

\section{Abstract}

Waste generated from health care centres and its management are emerging issues in India. The improper management of such wastes has adverse impact on health and environment. Though these wastes constitute a small portion of the total waste but very special handling, treatment and disposal are needed to manage such wastes because of their highly toxic and infectious nature. There are seven major specialized government hospitals in Cuttack City. According to the Chief District Medical Officer, Cuttack there are 229 registered and more than 300 unregistered nursing homes, clinics, pathology and diagnostics centres also which generate huge quantity of biomedical wastes. Most of the health care centres of the City are either dumping the wastes in the municipal bins or Mahanadi river and Taladanda canal side or hand over the waste to the unauthorised private parties. This is ultimately collected by rag pickers for reuse.Unlawful disposal of these wastes by healthcare centres can contribute to the spread of serious diseases such as hepatitis, AIDS (HIV) and other deadly diseases. The present study focuses upon the management practice followed in Cuttack City by the Hospitals and and large number of other health care centres and the impact of biomedical waste on environment. According to the study, the unethical open dumping and unsegregated mixed biomedical waste were found in municipal bins is a serious health hazards for rag pickers and also to the hospital staff and the public. The study also found that wastes generated from the radio diagnostics centres, and the laboratory units disposed off directly into the municipal sewer without proper disinfection of pathogens, ultimately flowing to the river Mahanadi and Kathajodi and also to the Taladanda canal through various drains of the city. The results of the study showed that there is an adverse impact of the biomedical wastes on Cuttack city due to mismanagement which needs strict enforcement of laws and other legal provisions for better environmental management system for the disposal of biomedical waste in order to bring back congenial and healthy environment for city dwellers.

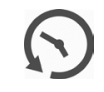

Article History

Received: 24 February 2018

Accepted: 02 July

2018

\section{Keywords}

Biomedical Waste, Health care centre.

CONTACT Puspalata Pal puspapal97@gmail.com 9 Ravenshaw Government Jr. College, Cuttack, India. (c) 8 (1)

(C) 2018 The Author(s). Published by Enviro Research Publishers.

This is an 6 Open Access article licensed under a Creative Commons license: Attribution 4.0 International (CC-BY).

Doi: http://dx.doi.org/10.12944/CWE.13.2.11 


\section{Introduction}

The infectious biomedical waste which is only 15 to $25 \%$ of the entire waste is not segregated and is mixed with general waste which ultimately turns the whole waste into infectious waste ${ }^{3}$. The same waste is dumped into municipal bins and in municipal dumping yards, then, therefore the whole wastes in municipal bins become infectious and the mixed wastes in open dumping yards make the environment filthy and hazards to the public spreading dangerous diseases.

The unethical disposal of mixed waste containing sharps, needles and anatomical wastes from surgeries cause injuries,cuts and various nosocomial infections and transmission of diseases like hepatitis B. hepatitis C, HIV etc. among the hospital staff, municipal workers, waste handlers, rag pickers and general public ${ }^{4}$. The reuse of needles, syringes and other articles by the patients not only worsens ones conditions but also but also take someone to the threshold of death. Careless and unethical dumping facilitates the poor and destitute who are encouraged by some traders to collect such waste which subsequently come to the market with repacking and selling. One of the reasons for spreading of infection is reuse of disposable items like syringes, needles, catheters IV and dialysis set etc (Tamplin et al., 2004). The dumping of untreated biomedical waste in open in Cuttack City enhances the chances of survivals, growth and alteration of pathogenic microbial population which leads to various types of communicable diseases, soil and ground water pollution. Chances of vectors are high like rodents, worms, mosquitoes, flies, stray dogs getting infected or becoming carriers which also spread diseases among public. Studies show that every year since 2012 the slum dwellers of Cuttack City residing in the Mahanadi river and Taladanda canal side are suffering from various communicable diseases. The residents nearby Krusak Bazar, Bidanasi where the municipal dumping yard is located is also vulnerable to infectious diseases. Other diseases like Jundice is also found every year in Jobra area of the city due to contamination of water. Various studies shows that the effects of used infected syringe and needle by patients are prone to HIV, Hepatitis B, Hepatitis C and other blood borne diseases.
The objective of the present study is to assess the biomedical waste management situation of Cuttack City and its impact on the city dwellers and environment. There are seven government run hospitals and large number of private nursing homes, clinics and diagnostics centres which generated huge quantity of biomedical waste. But lack of proper management and indiscriminate disposal of these wastes are the cause of concern for the inhabitants. The study also highlights the health impact of pharmaceutical wastes, chemical waste, cytotoxic/ genotoxic drugs, waste sharps, radioactive waste and uncontrolled burning of infectious biomedical waste for which the city inhabitants are suffering from various kinds of air and water borne diseases every year.

\section{Definition of Biomedical Waste}

According to the Biomedical waste (Management \& Handling )Rules 1998 of Govt of India "Biomedical Waste means any waste which is generated during the diagnosis, treatment or immunisation of human beings or animals or in research activities pertaining thereto or in the production or testing of biological, including categories mentioned in Schedule-1 (Table-1) appended to these rules " 1,2 . It is clear from the definition that Biomedical waste comprises both human \& animal anatomical waste, treatment apparatus like needles, syringes and other materials used in health care facilities in the process of treatment and research. These wastes are generated during diagnosis, treatment or immunisation in hospitals, nursing homes, pathological laboratories, blood bank, etc. (Table-2) gives the type of waste generated from different generation points.

Problems and Risks from Biomedical Waste and its need for safe management ${ }^{4,5,7}$

- Infectious wastes containing possible harmful microbes can infect patients, patients' attendants and health care personnel.

- Used needles, syringes, and other sharps present in biomedical waste cause risks of injury and infection for health care staff. (for example, hepatitis B and C, and HIV) Intoxication or injuries such as burns from chemical and pharmaceutical wastes. 
- $\quad$ Mutagenic and carcinogenic properties of genotoxic wastes which are hazardous and have harmful effects.

- Wastes from radioactive sources may cause terrible injuries to human beings such as tissue damage.

- $\quad$ Untreated liquid wastes from health care facilities contaminates ground and surface water and spreads water borne diseases like jaundice and cholera.

- $\quad$ Careless disposal of BMWs in open dumps increase the risk of injury from sharps and the spread of infectious diseases to house keeping staff, waste handlers, scavengers and the public.

- $\quad$ Open and uncontrolled burning of biomedical waste increases the risk of exposure to hazardous emissions.

- Environmental and health risks to local residents and incinerator operators due to poorly designed or operational biomedical waste incinerators as it emits carcinogenic dioxins and furans, formed through incomplete combustion at low temperatures .

- Harmful effects of untreated medical equipments and recycled products from biomedical waste.

- $\quad$ Untreated and carelessly managed solid and liquid biomedical waste is vulnerable to air, water and soil causing pollution.

Table - 3 gives various types of infections, causative organs and the transferral vehicles.

Table 1: Category of Biomedical Waste and its treatment and disposal options 1,2,3

Schedule -1-Biomedical waste category and treatments options as per BMW (Management \& Handling) Rules of Govt of India and as amended.

\section{Category of Type of Waste Category Wastes}

Category No.1

Anatomical Waste of Humans (parts of the body, tissues \& organs of humans).

Category No.2 Waste from Animals: (Tissues of animals, organs, body tissues, parts of body, carcasses, fluid, blood and animals used in research, waste from animal houses and veterinary hospital).

Category No.3 Laboratory, Microbiology \& Biotechnology waste (Wastes generated from blood bank, pathology, biochemistry, haematology and laboratory units, clinical samples, cultures, specimens / stocks of live microbes or attenuated vaccines, culture of human \& animal cell used in research, infected toxic agents from industrial research laboratories, culture transfer devices and dishes, wastes from production of biologicals).

Category No.4 Sharp waste - (Used and unused sharps which include syringes needles, glass syringes/, fixed needle syringes, glass, scalpels, blades, cutters etc. that may cause puncture and cuts and puncture.

Category No.5 Expiry medicines \& Cytotoxic drugs (Waste comprising of Expiry, ,outdated ,

\section{Options of Treatment \& Disposal method to be adopted}

Incineration /deep burial

Incineration /deep burial

Step-1(a)Pre chemical treatment for Disinfection at source. (b) Microwaving/Autoclaving followed by mutilation shredding Step-2-

(a)Final disposal in deep \& secured landfill by authorised registered agency(b) Disposal of plastics/glass/polythene by authorized registered agency.

To be disposed in secured landfill or incineration process.

To be disposed in secured landfill or incineration process. 
contaminated medicines).

Category No.6 Soiled waste: blood and body fluids including cotton, dressings, soiled plaster casts, linen, beddings and other material contaminated with blood.

Category No.7 Solid Infectious waste: Waste sharps such as tubings, hand gloves, saline bottles with IV tubes, catheters, glass, intravenous sets and other disposable wastes.

Category No.8 Waste from Chemicals (Chemicals used in disinfection such as insecticides etc.

\& production of biological.
To be disposed in incineration process.

To be disinfected by chemical treatment or autoclaving or microwaving followed by mutilation or shredding and after treatment final disposal through registered or authorized recyclers. Chemical treatment and discharge into drains compliance with norms notified under these rules and then to be disposed in secured landfill.

Source: Biomedical wastes (Management and Handling Rules, 1998), Govt of India and as amended

Table 2: Waste generation places of hospitals \& other health care centres 2,3

\begin{tabular}{|c|c|c|}
\hline $\begin{array}{l}\text { SI } \\
\text { No. }\end{array}$ & Waste points in health care centres & Category of waste generated \\
\hline 1 & Outdoor Patient Department (OPD) & $\begin{array}{l}\text { Syringe, needle, sharps, gauze, } \\
\text { bandage and plastics. }\end{array}$ \\
\hline 2 & Vaccination \& Injection room & $\begin{array}{l}\text { Syringe, needle, sharps, gauze, } \\
\text { bandage and plastics. }\end{array}$ \\
\hline 3 & Patients' General ward & $\begin{array}{l}\text { Syringe, needle, sharps, gauze, } \\
\text { bandage and other solid waste. }\end{array}$ \\
\hline 4 & Patients Labour room & $\begin{array}{l}\text { Anatomical waste, Syringe, needle, } \\
\text { sharps, gauze, bandage and other } \\
\text { solid waste. }\end{array}$ \\
\hline 5 & OT Room & $\begin{array}{l}\text { Anatomical waste, Syringe, needle, } \\
\text { sharps, gauze, bandage and other } \\
\text { solid waste. }\end{array}$ \\
\hline 6 & ICU unit/ emergency wards & $\begin{array}{l}\text { Syringe, needle, sharps, gauze, } \\
\text { bandage and plastics. }\end{array}$ \\
\hline 7 & Pathology \& Laboratory units & $\begin{array}{l}\text { Sharps waste, solid waste, soiled } \\
\text { waste, biological (culture media). }\end{array}$ \\
\hline 8 & Transfusion medicine \& Blood Banks & $\begin{array}{l}\text { Vacationers, Lancet, hypodermic } \\
\text { collection needles, plastic tubing, } \\
\text { PVC blood bags, slides, gauze } \\
\text { pieces, plastic tubes. }\end{array}$ \\
\hline 9 & X-Ray Units & Radioactive waste. \\
\hline 10 & Pharmacy & Expiry and outdated medicines \\
\hline
\end{tabular}


Table 3: Types of infections caused by subjection to wastes generated from health care centres, causative organisms, and transferral vehicles

\begin{tabular}{|c|c|c|}
\hline Type of infection & Samples of causative organisms & Transferral vehicles \\
\hline $\begin{array}{l}\text { Stomach and intestine } \\
\text { infections }\end{array}$ & $\begin{array}{l}\text { Enterobacteria, e.g. Salmonella, } \\
\text { Shigella spp.; Excrement and/or } \\
\text { vomiting, Vibrio cholerae; helminths }\end{array}$ & Excrement and/or vomiting \\
\hline Respiratory infections & $\begin{array}{l}\text { Mycobacterium tuberculosis; measles } \\
\text { virus, Streptococcus pneumoniae }\end{array}$ & Inhaled excretions; sputum \\
\hline $\begin{array}{l}\text { Infection connected with } \\
\text { eyes or vision }\end{array}$ & Herpes virus & Eye excretions \\
\hline $\begin{array}{l}\text { Human or animal } \\
\text { reproductive organ } \\
\text { infections }\end{array}$ & Neisseria gonorrhoeae; herpes virus & Genital excretion \\
\hline Epidermis infections & Streptococcus spp. & $\begin{array}{l}\text { Pus from infected tissue, } \\
\text { tissue debris and serum }\end{array}$ \\
\hline $\begin{array}{l}\text { Anthrax (bacterial disease } \\
\text { of sheep \& cattle }\end{array}$ & Bacillus anthracis & Skin excretions \\
\hline Meningitis & Neisseria meningitis & Fluid from from nervous system \\
\hline $\begin{array}{l}\text { Acquired immuno- } \\
\text { deficiency syndrome (AIDS) }\end{array}$ & Human immunodeficiency virus (HIV) & Blood, sexual excretions. \\
\hline Viral haemorrhagic fevers & $\begin{array}{l}\text { Junin, Lassa, Ebola, and Marburg } \\
\text { viruses }\end{array}$ & $\begin{array}{l}\text { All bloody products and } \\
\text { Excretions and bloody }\end{array}$ \\
\hline $\begin{array}{l}\text { Blood poisoning caused by } \\
\text { bacteria(Septicaemia) }\end{array}$ & Staphylococcus spp. & $\begin{array}{l}\text { products } \\
\text { Blood }\end{array}$ \\
\hline $\begin{array}{l}\text { Presence of bacteria in } \\
\text { blood (Bacteraemia) and } \\
\text { Streptococcus spp }\end{array}$ & $\begin{array}{l}\text { Coagulase-negative Staphylococcus } \\
\text { aureus; Enterobacter, Enterococcus, } \\
\text { Klebsiella, }\end{array}$ & \\
\hline Candida & Candida albicans & Blood \\
\hline Viral hepatitis $A$ & Hepatitis A virus & $\begin{array}{l}\text { Excrement/discharge from the } \\
\text { bowels }\end{array}$ \\
\hline Viral hepatitis $B$ and $C$ & Hepatitis $B$ and $C$ viruses & Hepatitis $B$ and $C$ viruses \\
\hline
\end{tabular}

\section{Impacts of Infectious Waste and Sharps}

The highest rate of disease transmission usually comes from infectious biomedical waste and sharps which mostly include syringes and needles. The highest rate of injuries are also found among staff during the use of sharp material and its subsequent disposal. The prime threat is the transmission of HIV virus, Hepatitis $B$ and $C$ through cuts and injuries caused by syringes contaminated with blood ${ }^{4,6}$.

Studies show that more than $50 \%$ nursing personnel usually are more prone to needle stick injury whereas other medical staff like attendants, house keeping staff, laboratory technicians, pharmacists and other paramedical staff together come across rest of the needle stick injury during their medical duty ${ }^{4,5,7}$.

\section{Impacts of Chemical and Pharmaceutical} Waste

Hospital staff like Pharmacists, anaesthetists, nursing sisters, house keeping and maintenance staff are more prone to respiratory or skin diseases caused by chemical or pharmaceutical waste substances like fumes, aerosols, liquids, solvents from disinfectant X-Ray film, chemotherapeutic or anti cancer drugs, outdated medicines and smokes from incinerators. Some hazardous chemicals used in health care facilities are also carcinogenic and pose health risks to hospital workers, patients, and community ${ }^{4,6}$ 
Table 4: Chemicals used in Health Care Centres and its impacts

\begin{tabular}{|c|c|c|c|}
\hline Chemicals & Commercial & $\begin{array}{l}\text { Purpose of use } \\
\text { Product }\end{array}$ & Toxic effect \\
\hline Alcohols & $\begin{array}{l}\text { Rubbing alcohol } \\
\text { (70\% ethanol) }\end{array}$ & $\begin{array}{l}\text { Cleaning antiseptic, } \\
\text { disinfectant }\end{array}$ & $\begin{array}{l}\text { CNS depression, respiratory } \\
\text { depression, dermal irritation }\end{array}$ \\
\hline \multicolumn{4}{|l|}{ Ethanol } \\
\hline Isopropanol & $\begin{array}{l}\text { Isopropyl rubbing } \\
\text { alcohol( } 70 \% \\
\text { isopropanol) }\end{array}$ & Antiseptic, disinfectant & $\begin{array}{l}\text { CNS depression,Respiratory } \\
\text { depression, dermal irritation, } \\
\text { ketonemia, ketonuria, } \\
\text { Gastroenteritis / bleeding, } \\
\text { hemorrhagic hypotension, } \\
\text { tracheobronchitis }\end{array}$ \\
\hline $\begin{array}{l}\text { Acids } \\
\text { Boric acid }\end{array}$ & $\begin{array}{l}\text { Borax sodium perborate, } \\
\text { Dobell's solution }\end{array}$ & $\begin{array}{l}\text { Antiseptic, mouthwash, } \\
\text { eyewash, cockroach } \\
\text { killer }\end{array}$ & vomiting and diarrhoea \\
\hline Acid gases & $\begin{array}{l}\text { Hydrochloric acid }(\mathrm{HCl}) \text {, } \\
\text { Nitrogen oxide }\left(\mathrm{NO}_{2}\right) \\
\text { Sulphur dioxide }\left(\mathrm{SO}_{2}\right)\end{array}$ & $\begin{array}{l}\text { Fixing of sputum slide } \\
\text { Laboratory use }\end{array}$ & $\begin{array}{l}\text { Burning sensation (inhalation } \\
\text { causes coughing, restrict } \\
\text { breathing, Eye inflammation } \\
\text { and respiratory problems }\end{array}$ \\
\hline Peroxy acetate & & Laboratory patient care & $\begin{array}{l}\text { Mucous membrane irritant, } \\
\text { promote skin tumor }\end{array}$ \\
\hline Aldehydes & Formalin $37 \%$ & Disinfectant & \\
\hline Formal dehyde & formal dehyde & $\begin{array}{l}\text { Urea formaldehyde } \\
\text { foam insulation }\end{array}$ & $\begin{array}{l}\text { Gastroenteritis, CNS } \\
\text { depression }\end{array}$ \\
\hline Glutaraldehyde & Citadex & Sterilant & Mucosal and dermal irritant, \\
\hline Chlorohexidine & (2\% Hibiciens) & Antiseptic & Gastroenteritis \\
\hline $\begin{array}{l}\text { Chlorinated } \\
\text { compounds } \\
\text { Chlorine }\end{array}$ & $\begin{array}{l}\text { Chlorine bleach } \\
(5 \% \mathrm{NaOCl})\end{array}$ & Disinfectant & Irritant \\
\hline $\begin{array}{l}\text { Sodium } \\
\text { hypochlorate }\end{array}$ & $\begin{array}{l}\text { Dakins solution } \\
\text { (1part } \mathrm{NaOCl} \\
+10 \text { parts } \mathrm{H}_{2} \mathrm{O}\end{array}$ & Disinfectant & Mild Gastroenteritis \\
\hline $\begin{array}{l}\text { lodinated } \\
\text { compounds }\end{array}$ & $\begin{array}{l}\text { Tincture of iodine } 2 \% \\
2 \% \text { sodium iodide, } \\
\text { free iodine, } 5 \% \text { ethanol }\end{array}$ & Antiseptic & Gastroenteritis \\
\hline \multicolumn{4}{|l|}{ lodine } \\
\hline lodophors & $\begin{array}{l}\text { Povidone-lodine } \\
\text { (Betadine) }\end{array}$ & Antiseptic & Iodism \\
\hline lodide & sski & Expectorant & Iodism \\
\hline Heavy Metal & Merbromin & Antiseptic(obsolate) & III effects on CNS and \\
\hline Organic & $2 \%($ mercurochrome $)$ & & renal system \\
\hline Mercurials & Thimerosal(merthiolate) & & \\
\hline Mercury & & $\begin{array}{l}\text { Hospital equipments } \\
\text { Dental amalgam }\end{array}$ & $\begin{array}{l}\text { Carcinogenic,mutagenic and } \\
\text { teratogenic effects }\end{array}$ \\
\hline Oxidants & $\begin{array}{l}\text { Sodium chlorate } \\
\text { Potassium chlorate } \\
\text { Chlorates }\end{array}$ & $\begin{array}{l}\text { Antiseptic Mouthwash, } \\
\text { herbicide }\end{array}$ & $\begin{array}{l}\text { Hemolytic anaemia } \\
\text { Methemoglobinemia renal } \\
\text { failure }\end{array}$ \\
\hline Hydrogen & $\mathrm{H}_{2} \mathrm{O}_{2} 3 \%$ & Disinfectant Antiseptic & Gas embolism \\
\hline
\end{tabular}




\begin{tabular}{|c|c|c|c|}
\hline peroxide & $\mathrm{H}_{2} \mathrm{O}_{2} 30 \%$ & & $\begin{array}{l}\text { Cause blood vessel } \\
\text { blockage Manganese } \\
\text { elevation } \\
\text { Methemoglobinemia }\end{array}$ \\
\hline $\begin{array}{l}\text { Phenols } \\
\text { Non-substituted }\end{array}$ & Phenol(carbolic acid) & Disinfectant & $\begin{array}{l}\text { Dermal burns, cutaneous } \\
\text { absorption, CNS effects }\end{array}$ \\
\hline Substituted & Hexachlorophene & Disinfectant & CNS disturbances \\
\hline $\begin{array}{l}\text { Quaternary } \\
\text { Ammonium } \\
\text { compound } \\
\text { Benzalkonium } \\
\text { chloride }\end{array}$ & Zephiran & Disinfectant & $\begin{array}{l}\text { Gastroenteritis at higher } \\
\text { concentration }\end{array}$ \\
\hline Ethylene oxide & & Sterilant & $\begin{array}{l}\text { Irritant, CNS depression, } \\
\text { Peripheral Necropathy, } \\
\text { Carcinogen }\end{array}$ \\
\hline Xylene & & $\begin{array}{l}\text { Removal of } \\
\text { cedarwood oil } \\
\text { for TB slide }\end{array}$ & Euphoria, skin, eye irritation \\
\hline
\end{tabular}

Open burning of infectious waste and waste incineration release extremely harmful pollutants such as dioxins into the environment. The effects of dioxins include cancer, birth defects, alterations in the reproductive system, impacts in child development, suppression of the immune system, female infertility, lower sperm count in males and spreading of other deadly diseases ${ }^{4,7}$.

Table 5: Pollutants from crude burning and Low temperature waste incineration of Bio medical waste and their toxic effects

\begin{tabular}{|c|c|c|}
\hline Pollutants & Examples & Toxic effect \\
\hline $\begin{array}{l}\text { Poly Nuclear } \\
\text { aromatic hydro- } \\
\text { carbons (PAHS) }\end{array}$ & $\begin{array}{l}\text { Phenanthrene, pyrene } \\
\text { Benzopyreneovalene }\end{array}$ & $\begin{array}{l}\text { Cancer,cardiovascular diseases, } \\
\text { poor foetal development }\end{array}$ \\
\hline $\begin{array}{l}\text { Polychlorinated } \\
\text { dibenzofurans } \\
\text { (PCDFs) }\end{array}$ & $2,3,7,8$ tetraclorodibenzofuran & $\begin{array}{l}\text { Chlorance genetoxic carcinogenic } \\
\text { (skin disorder)Liver problem, effects } \\
\text { on developing nervous } \\
\text { system impairment of the immune } \\
\text { system, endocrine }\end{array}$ \\
\hline $\begin{array}{l}\text { Polychlorinated } \\
\text { dibenzo para- } \\
\text { dioxins(PCDDs) }\end{array}$ & $\begin{array}{l}\text { 2,3,7,8 pentachlorinated } \\
\text { dibenzo-para dioxins }\end{array}$ & $\begin{array}{l}\text { Reproductive (Abnormal testis, } \\
\text { lower testosterone,male feminization } \\
\text { ovarian dysfunction Chlorance,skin } \\
\text { defect damage immune system } \\
\text { Cancer(genotoxic carcinogenic }\end{array}$ \\
\hline $\begin{array}{l}\text { Chlorinated } \\
\text { biphenyls (PCBs) }\end{array}$ & $\begin{array}{l}\text { Used as an insulating material in } \\
\text { electric equipments (transformer } \\
\text { capacitor) and also heat transfer } \\
\text { fluid and lubricants }\end{array}$ & $\begin{array}{l}\text { Probable human carcinogenic } \\
\text { (genotoxicity, chlorance,eye } \\
\text { problem, irritation of nose, longs) }\end{array}$ \\
\hline Heavy metals & $\begin{array}{l}\text { Arsenic, chromium, lead, mercury, } \\
\text { cadmium, nickel, manganese }\end{array}$ & $\begin{array}{l}\text { Pulmonary, nervous, renal, skeletal, } \\
\text { hemopoietic, skin abnormality }\end{array}$ \\
\hline Carbon monoxide & Product of incomplete combution & Carbon monoxide Poisoning leads to \\
\hline
\end{tabular}




$\begin{array}{ll}\text { Acid gases } & \text { HCL, HF, Hydrogen - } \\ & \text { sulphur dioxide,Nitrogen oxide } \\ \text { Particulate matter } & \text { Fly ash }\end{array}$

Bottom ash residue
Usually contaminated with dioxins, furans, other organics and leachable heavy metal death, reduce oxygen transportation Corrosive,skin irritation

Diarrhoea, brain, liver, lung, kidney, heart damage Cancer, cardiovascular disease

\section{Impacts of Genotoxic Waste}

Direct contact or exposure to genotoxic materials have serious consequences on human health and environment as it is carcinogenic and mutagenic. It causes mostly skin and eye diseases. Contact like mouth pipetting, preparation during drug therapy,contact with the bodily fluids, secretions of patients undergoing chemotherapy, ingestion of food contaminated with cytotoxic drugs and chemicals have also harmful effects like dizziness, nausea, headache or dermatitis ${ }^{4,5,7}$.

Table 6 : Geno-toxic/cytotoxic drugs used in human health care

\begin{tabular}{ll}
\hline GENO-TOXIC /CYTOTOXIC DRUGS & Impact \\
\hline Azathioprine & Hepatosplenic T-cell (carcinogenic lymphoma) \\
Busulphan & Teratogenic mutagenic (carcinogenic) \\
Cyclosporine A & Teratogenic mutagenic (carcinogenic) \\
Cyclophosphamide & Teratogenic mutagenic (carcinogenic) \\
Cisplatin & Mutagenic (carcinogenic) \\
Lansoprazole & Positive \\
Omeprazole & Carcinogenic \\
Phenacetin & Renal carcinogenic \\
Androgenic steroid & Carcinogenic \\
Oxazepam & Hepato carcinogenic \\
Chloramphenicol & Induce Chromosomal aberration (mutation of lymphocyte) \\
Tamoxifen & Endometrial carcinogenic \\
Estrogen & Carcinogenic \\
Progesterone & Carcinogenic \\
\hline
\end{tabular}

\section{Impacts of Radioactive Waste}

Infected or contaminated radio nuclides generated from in-vitro analysis of body tissues and fluid, unscientific and improper handling of radiotherapy solutions, unsafe management of X-Ray instruments, unscientific disposal of nuclear therapeutic materials,exposure and access to ionizing radiations in health-care centres and radioactive waste etc. have serious health impact ${ }^{8}$.

\section{Biomedical Situation of Cuttack City}

Cuttack is one of the oldest city in India and second largest corporation in the state of Odisha with a total population 606.007 individuals as of the 2011 census. Spread across an area of $298 \mathrm{sq} \mathrm{km}$, the city of Cuttack is situated at the apex of the Mahanadi River Delta and is located about $28 \mathrm{~km}$ north of Bhubaneswar, the capital of Odisha Cuttack City is the former capital of Odisha and the current headquarters of Cuttack district. The city is popularly known as the Health Hub of eastern India. There are seven major specialized government hospitals in Cuttack City and according to the Chief District Medical officer, Cuttack there are also 229 registered and more than 300 unregistered Nursing Homes, Clinics, Pathology and Diagnostics centres which generated huge quantity of biomedical wastes. Biomedical wastes include human anatomical waste 
like tissues, organs, body parts, as also animal waste, microbiological and biotech-nological waste, hypodermic needles, syringes, scalpels, broken glass, discarded medicines, dressing's bandages, catheters, incineration ash, etc. ${ }^{2}$ The Biomedical waste management practices in the city is highly deficient and grossly neglected. The wastes get mixed up with municipal solid waste and deposited at the common disposal site. The Cuttack Municipal Corporation is not collecting Biomedical waste from the health care centres. Rather some agencies are engaged to collect biomedical waste specifically from the seven government run hospitals and taken the waste to the waste treatment facility where the biomedical waste are not managed in scientific manner. Despite media campaign and judicial inspection to the major government hospitals of the city, there still exist missing links that have serious implications for both human health and urban ecology of Cuttack.

Present Status of Biomedical Waste Management of Hospitals, Nursing Homes, Clinics, Pathology and Diagnostic Centres of Cuttack City

Improper and unscientific management of Biomedical waste handling and management is an emerging issue in Cuttack City which is surrounded by Mahanadi and Kathajodi river as there is large number of hospitals, nursing homes, clinics, pathology and diagnostic
Centres presence across every lanes of the city. Solid biomedical waste(both clinical and non-clinical) generated from these health care centres except some Govt and private hospitals are collected in open bins without disinfection. Though colour coding bins are kept for different categories of waste but no segregation and improper collection of wastes are noticed during my survey except a few private and govt Hospitals. Rather sorting of used disposables for reuse are found without disinfection. Rag pickers are also collecting these dangerous waste for reselling ultimately spreading infections. It is also noticed that used plastics, glass, intravenous sets, bottles, sharps, syringes are sold to third party. Some wastes are also found in the Municipal bins in various places of the city. These infectious wastes are transported by the waste collector by hand-held cart to Municipal dumping yard and are found to be disposed on road side /open pits without safety precautions. Open burning of these wastes in the Mahanadi and Kathajodi river and Taladanda canal side cause air pollution and toxic ash. No fencing is noticed in the dumping yard to keep the rag pickers away causing serious health impacts. People very often raising their concern due to unsafe disposal of these wastes, unaesthetic conditions, odour nuisance and ground water pollution of the area. Table-7 gives untreated and unsegregated biomedical waste found in open bins in various locations of the city.

Table 7: Untreated and unsegregated biomedical wastes collection locations in open bins

\begin{tabular}{lllll}
\hline $\begin{array}{l}\text { Location of waste } \\
\text { collection bins }\end{array}$ & $\begin{array}{l}\text { Waste } \\
\text { collection bins }\end{array}$ & Segregation & $\begin{array}{l}\text { Treatment } \\
\text { ement practice }\end{array}$ & Waste manag- \\
\hline $\begin{array}{l}\text { Mallaha Sahi, } \\
\text { Mangalabag }\end{array}$ & $\begin{array}{l}\text { Mixed waste found } \\
\text { in open bins }\end{array}$ & No & No & $\begin{array}{l}\text { Unethical \& } \\
\text { unscientific practice }\end{array}$ \\
$\begin{array}{l}\text { Ranihat, } \\
\begin{array}{l}\text { Medical Road } \\
\text { Mixed waste found }\end{array}\end{array}$ & No & No bins & No & Unethical \& \\
$\begin{array}{l}\text { Samadhipatna } \\
\text { and Pareswar Sahi, } \\
\text { Jobra Road }\end{array}$ & $\begin{array}{l}\text { Mixed waste found } \\
\text { in open bins }\end{array}$ & No & No & unscientific practice \\
$\begin{array}{l}\text { Samant Sahi, } \\
\text { Canal Road }\end{array}$ & $\begin{array}{l}\text { Mixed waste } \\
\text { found in open bins }\end{array}$ & No & Unethical \& \\
unscientific practice
\end{tabular}


Similarly infectious liquid waste are flown to the septic tanks, open drains and to the nearby Taladanda canal and Kathojodi river around the city which cause health concerns to the city residents. Very often the drains are found over-flowing and in precarious conditions. Every year the city is in the headlines of the news paper and electronic media for spreading of various diseases due to contamination of water and air. The New Indian Express reported on 18 February 2018 that 43 persons, including 31 from Jobra's Samadhipatana and Pareswar Sahi and 12 from Nuapada, were suffering from the water-borne disease. Unofficial sources, however, put the figure at much higher as patients continued to pour in at hospitals from different part of the city. Use of contaminated drinking water due to leakage in pipelines coming in contact with the infected liquid waste is suspected to be the cause behind resurgence of the disease. The Deccan Herald reported on February 2015 the outbreak of jaundice in Cuttack City. The New Indian Express also reported on 3 January 2014 the jaundice and cholera outbreak in the city. The Times of India on 13 January 2017 and The Hindu on 28 February 2017 reported about 100 jaundice cases in Tulsipur area of the city. In Table-8 provides location of infectious liquid waste flown and residents affected in the area suffering from jaundice and cholera in 2017.

Table 8: Locations of infectious liquid waste flown to sewage and open drains in the city and residents affected by jaundice and cholera in 2017.

\begin{tabular}{llllll}
\hline $\begin{array}{l}\text { Locations of } \\
\text { infectious liquid } \\
\text { waste flown }\end{array}$ & $\begin{array}{l}\text { No of people } \\
\text { interacted }\end{array}$ & $\begin{array}{l}\text { No of suffering } \\
\text { cases }\end{array}$ & \begin{tabular}{l} 
No of people who \\
believe/confirm due \\
to biomedical waste \\
\cline { 3 - 5 } disposal problem
\end{tabular} & $\begin{array}{l}\text { \% age of } \\
\text { suffering } \\
\text { cases }\end{array}$ \\
\hline $\begin{array}{l}\text { Jobra, } \\
\begin{array}{l}\text { Samadhipatna } \\
\text { Jobra, }\end{array}\end{array}$ & 40 & 31 & 07 & 40 & 95 \\
$\begin{array}{l}\text { Paraswar Sahi } \\
\text { Nuapada }\end{array}$ & 30 & 22 & 05 & 30 & 90 \\
\hline
\end{tabular}

\section{Discussion}

During the study it was noticed that all the health care institutions of Cuttack city some way or other were not following the rules prescribed by the authority and manage these hazardous waste at their own will putting public life and environment into danger for which the inhabitants are continuously suffering from various kinds of epidemics and transmittable diseases every year. Despite enactment of time to time legislations and framing of rules for scientific management of biomedical wastes for clean and green environment,but the health care institutions of the city are not following the guidelines and facing irreparable loss and damage to human and environmental resources.

As biomedical wastes are not properly handled and carefully managed, the city is always in the news for spreading of dengue fever, jaundice and other diseases most of the time in a year. Many hospitals and health care centres in the city handed over the waste to private parties or even dumping them in the municipal garbage bins despite provisions to entrust the management to an authorized agency to handle the hazardous biomedical waste. Both general and infectious biomedical waste were found in the bins kept in the premises of hospitals and health care centres indicated that wastes were not segregated in different colour coded bins as per the law and these institutions were openly violating the biomedical waste management rules in Cuttack city. Biomedical Waste (Management \& Handling) Rules, 1998 of Govt. of India provided a regulatory framework for management of biomedical waste generated in the country. Subsequently Govt. of India reviewed the rules and amended it in the year 2000, 2003, 2011 and 2016 for the proper implementation of these rules more effectively and to improve the collection, segregation, processing, treatment and disposal of these biomedical wastes in an environmentally 
sound manner reducing its generation and impact on the environment. But during the study it was revealed and found that most of the hospitals and health care centres are not serious about implementation of the biomedical waste management rules and admitted that they are handing over the waste to private agency without supervising its subsequent management. The study also found the effect and impact of indiscriminate disposal of pharmaceutical wastes, chemical waste, cytotoxic / genotoxic drugs, waste sharps, radioactive waste and uncontrolled burning of infectious biomedical waste on residents for which the city inhabitants are suffering from various kinds of air and water borne diseases every year.

\section{Conclusion}

Prior to 1998, before the enforcement of Biomedical waste management rules in India, usually the hospital wastes are either dumped or disposed of with the municipal wastes in landfills which led to spread of HIV, hepatitis B virus (HBV) and other contagious diseases which raised public awareness and concerns about proper and scientific disposal of biomedical waste. As per law, medical waste is required to be treated and managed in a scientific manner suggested for different categories of wastes and not to be mixed with municipal waste at any cost. Therefore Cuttack City which generates huge quantity of biomedical wastes needs special attention for proper scientific biomedical waste management solution to safeguard the environment and healthy living conditions for the inhabitants.

\section{Acknowledgement}

The present research was carried out and supported by the authors of this paper. We deeply thank to our colleagues, staff and well wishers who supported their expertise and experience in providing insight to this work that assisted the research. W e thank to staff of Hospitals, Clinics, Nursing Homes and working personnel of waste management agencies who provided us support in conducting the field study and survey for the research work.

\section{References}

1. Biomedical W aste (Management and Handling) Rules 1998, Ministry of Environment and Forest, Government of India and as amended : (http://envfor.nic.in/ legis/hsm/ biomed.html)

2. Biomedical Waste Management Rules 2016, Ministry of environment, forest and climate Change, Government of India Rules. 2016.

3. National Guidelines on Hospital Waste Management Based upon the BioMedical Waste (Management and Handling) Rules, 1998, New Delhi: MoHFW ; 2002 Government of India, Ministry of Health and Family Welfare (MoHFW).

4. Impact of Biomedical Waste on City Environment: Case Study of Pune, India. www.iosrjournals.org
5. Pruss E, Giroult P, Rushbrook. Safe management of waste from health-care activities, W HO Library Cataloguing-inPublication Data, 1999.

6. Li C, Fu-Tien J. Physical and Chemical Composition of Hospital Waste, Infection Control and Hospital Epidemiology.1993; 14(3):145.

7. Bdour A. 2004 Guideline for the Safe Management of Medical, Chemical, and Pharmaceutical Waste. National Institute for Environmental Training, Riyadh, Saudi Arabia.

8. Silva CE, Hoppe AE, Ravanello MM, Mello N. 2005 Medical waste management in the south of Brazil. 